\title{
Erratum to: Strategic and transactional costs of corruption: perspectives from Vietnamese firms
}

\author{
Thang V. Nguyen ${ }^{1,2} \cdot$ Bao D. Ho ${ }^{1}$ Canh Q. Le ${ }^{1}$. \\ Hung V. Nguyen ${ }^{1}$
}

Published online: 7 May 2016

(C) Springer Science+Business Media Dordrecht 2016

\section{Erratum to: Crime Law Soc Change DOI 10.1007/s10611-016-9609-7}

The name of the second author is Bao D. Ho. His name is now corrected above and in the published version of the article.

The online version of the original article can be found at http://dx.doi.org/10.1007/s10611-016-9609-7.

Thang V. Nguyen

nguyenvanthang@neu.edu.vn

1 National Economics University, Hanoi, Vietnam

2 IPAG Business School, Paris, France 